\title{
EL ROL DE LOS INTELECTUALES PÚBLICOS EN LA SOCIEDAD
}

La nueva edición de Anales de la Universidad de Chile tiene por objetivo convocar a la reflexión sobre el rol del intelectual en el espacio público, es decir, en el ámbito que pertenece a todos y es comúnmente ejercido por la colectividad, trascendiendo de esta forma las voluntades personales individuales.

Se trata de un tema vasto que implica un sinfín de interpretaciones en torno a las definiciones que el concepto de intelectual ha tenido, sus relaciones y funciones en el espacio o dominio público, sus ideologías, sus prácticas y teorías en juego. Un tema que nos interroga sobre la significancia política de las humanidades en el contexto actual y, de este modo, nos invita a reconocernos históricamente en -tal como diría Gadamer- la "interacción comprensiva", con ciertos vestigios que prueban la función social del intelectual como generador de fuerzas persuasivas deliberadas con el objeto de influir, mediante el racionamiento, en el diálogo y comportamiento social. Aquí residiría el objeto del deseo, la pasión y la misión del intelectual.

En los documentos reeditados se destacan ciertos temas en común:

-La relación de los intelectuales en la construcción de sus objetos de estudio como expresión de las clases sociales que representan. Tal como lo expresó en 1954 Gabriela Mistral en el discurso de recepción del Grado Doctor Honoris Causa: "es el privilegio que debemos pagar como un diezmo que viene de lejos, expreso o tácito este devengar debe ser bien cumplido y aunque él no sea cobrado explícitamente, el caso es el de pagar sin llamado ni presión alguna”.

Tema que también encontramos presente en el discurso de incorporación de 1926 de Inés Echeverría, primera mujer académica de la Facultad de Filosofía y Letras de la Universidad de Chile, autodefinida como "aristócrata" y selecta escritora, quien mantenía una relación casi espiritual con la escritura.

Ambos documentos, en distintos momentos de la historia de Chile, permiten analizar las complejas relaciones de género existentes en el campo intelectual y sobre todo lo difícil de llevar a cabo la labor cuando se escribe en femenino.

-La necesidad de vincularse entre los intelectuales a nivel continental se expresa en el trabajo de Francisco Walker, La Cooperación intelectual internacional y americana: la Comisión chilena de cooperación internacional, publicado en 1929. El texto aborda cómo la república de las letras latinoamericanas con capital cultural en París se expresó 
a través de la Sociedad de las Naciones en la Comisión Chilena de Cooperación Intelectual. El documento que publicamos permite analizar el sentido de dicha institucionalidad cultural que lideraba la Universidad de Chile en el país a finales de la década del 30.

Se trata, en definitiva, de un corpus de documentos, dos de ellos aparecidos en las propias páginas de Anales de la Universidad de Chile, que permiten analizar críticamente el lugar de la Universidad de Chile en tanto primera institución superior republicana abocada al propósito no solo de instruir saberes, sino de enriquecer la conciencia formando las voluntades afines para crear conocimiento crítico en el país. Asimismo, permiten interrogarnos sobre las circunstancias, las condiciones sociales particulares que explican el trabajo intelectual.

Alejandra Araya Espinoza Doctora en Historia, El Colegio de México Ariadna Biotti Silva Doctora en Historia, L'Ecole des Hautes en Sciencies Sociales Archivo Central Andrés Bello 